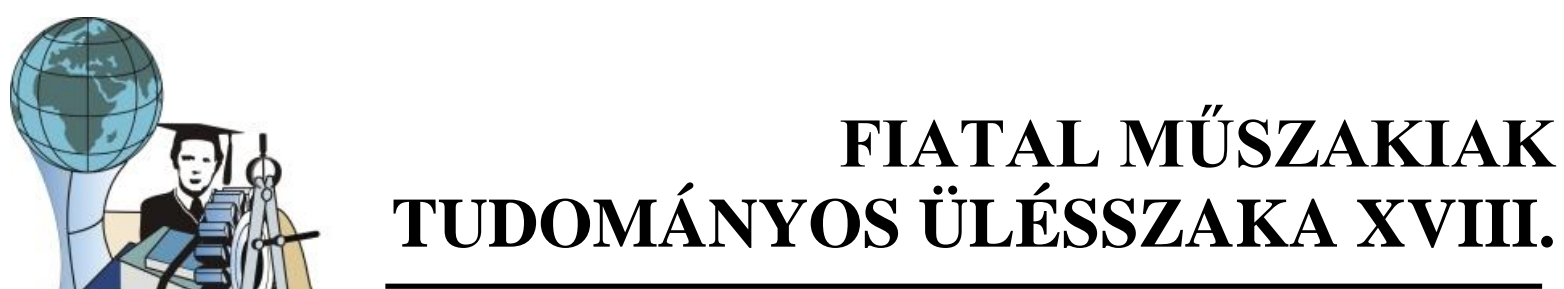

Kolozsvár, 2013. március 21-22.

\title{
ÉPÍTŐANYAGOK KAPCSOLATA A BELTÉRI ELEKTROSZMOGGAL
}

\author{
Vizi Gergely Norbert
}

\begin{abstract}
There is an increase in the spreading of wireless telecommunication, which rises health question in many people and researcher. This makes it more and more important to take into consideration and indicate among the wellknown constitutive parameters of building materials the properties connected to electromagnetic behavior. In this paper a short summary is given about such parameters of some basic building materials, and through computer simulations of the same virtual reference building with different building materials it will be compared and showed the different in house electrosmog level, first without any openings then with openings. Conclusions will be given in material usage, and in shielding aspects.
\end{abstract}

Key words:

Building material, permittivity, conductivity, in-house electrosmog, sick building syndrome

\begin{abstract}
Összefoglalás
Napjainkban a gyorsan terjedő vezeték nélküli kommunikáció terjedésével és ennek egészségügyi hatásainak kérdéseivel egyre inkább fontos az építőanyagaink jól ismert tulajdonságain kívül a dielektromos tulajdonságaikat is figyelembe venni és az anyagtáblázatokban feltüntetni. Ebben az írásban egy rövid összefoglalót adok a főbb építőanyagok ilyen tulajdonságairól, valamint számítógépes szimulációkon keresztül mutatom be és hasonlítom össze ugyanannak a virtuális minta-épületnek különböző anyagokból épített változatában keletkező beltéri elektroszmogot ablaknyílás nélküli, és ablaknyílással ellátott állapotban. Következtetést vonok le anyaghasználattal és árnyékolási szempontokkal kapcsolatban.
\end{abstract}

\section{Kulcsszavak:}

Építőanyagok, dielektromos tényező, vezetőképesség, beltéri elektroszmog, beteg épület sziondróma

\section{Bevezetés}

Napjainkban egyre gyorsabban fejlődő és elterjedő vezeték nélküli kommunikációs hálózatok szövik át a világot, hálózzák be a városainkat, de még nem teljesen tisztázott ezeknek biológiai hatása a környezetünkre, valamint az emberi szervezetre, de a kutató feladata hogy vizsgálja, ezek hatását és megelőzze az esetleges egészségügyi következményeket. Egyre inkább elterjedő fogalom az angol Sick Building Sindrome (Beteg épület szindróma), ami olyan betegségekre utal, ami az egészségtelen lakókörnyezet miatt alakul ki, aminek lehet oka a kevés fény, penészedés, dohos környezet, vagy a túlzottan magas elektromágneses sugárzás [1]. Mint építéstudománnyal, építészettel foglalkozó szakember, meg kell vizsgálni az építőanyagok hatását és viselkedését az újonnan megjelenő környezeti hatásokkal, mint pl. elektromágneses sugárzásokkal szemben is. 


\section{2. Építőanyagok}

Építőanyagoknak összetett tulajdonságaik vannak: tömeg, sűrüség, nyomószilárdság, rugalmassági modulus, hővezetési tényező, stb. Ezeken a napjainkban jól ismert tulajdonságokon kívül az anyagok rendelkeznek elektromos tulajdonságokkal, amik meghatározzák, hogy mennyire áll ellen az alacsony, illetve magas frekvenciás rádióhullámoknak. Ezek a paraméterek a frekvencia függvényében változnak, ezért nem lehet egy konkrét értéket megadni, a gyakran használt frekvencia tartományokban kell ezeket meghatározni.

A következőkben néhány építőanyag irodalomban fellelhető elektromos paramétereit mutatom be.

Tégla az egyik leggyakoribb építőelem, 1.7-18GHz között végzett vizsgálatok a dielektromos állandót ( $\varepsilon$ ) 4,62 és 4,11 (-) között, nem lineárisan változóként adja meg. A vezetőképesség ( $\sigma$ ) 0,0174 - 0,0364 (S/m) között változott [3].

Beton építőanyag előállítása az összetevők (homokos kavics, cement, víz) különböző arányú összekeverésével történik, így feltételezhetjük, hogy a különböző keverési arányok más dielektromos tulajdonságokat mutatnak. A vizsgálatok 1-9GHz között, a beton száraz állapotában folytak, és a szerzők [4][5] a komplex dielektromos állandót (permittivitást) 5-7 között mérték, az imaginárius részt pedig 0,1-0,7 között. Az imaginárius részből számolható a vezetőképesség (1):

$$
D x H=j \omega \varepsilon_{0}\left(\varepsilon_{r}+\frac{\sigma}{j \omega \varepsilon_{0}}\right) E
$$

Könnyübeton esetén a komplex permittivitás 2-2,5 között változott, az imaginárius rész pedig 0.12-0.5 között.

A vizsgálatokból megállapítható, hogy a beton minták permittivitása nem változik szignifikánsan a frekvencia vagy a keverési arányok függvényében, azonban jelentős különbség látható a normál és a könnyübeton között.

Vasalt beton szerkezetek esetén az összefüggő vasalat is hatással van az egész szerkezet dielektromos tulajdonságára, ezért ezeknél a falaknál az olyan paramétereket, mint a vasalatok távolsága és átmérője, is figyelembe kell venni.[6]

Üveg, föleg napjainkban, egyre nagyobb felületét foglalja el az épületeknek, ezért fontos ezzel az anyaggal is foglalkoznunk. Az üveg dielektromos állandója, ugyan úgy, mint a betoné, erősen függ az üveg összetételétől, de nem függ a frekvenciától. A kereskedelmi üvegek esetében ez 4-9 körüli érték. A tangens $\delta$, az a paraméter, ami leírja a veszteségeket az anyagban, értéke pedig 0,00005-0,035 közötti [7] nagyon kicsi érték. Mivel az üveg maga is vékony szerkezet ezért elhanyagolható a hatása belső térre. Ezt az állítást CST Microwaves Studio programban, egy olyan szimulációs programban ellenőriztem, ami a Maxwell egyenleteket véges elemes integrálással megoldva ad eredményt minden egyes vizsgálandó pontban. 

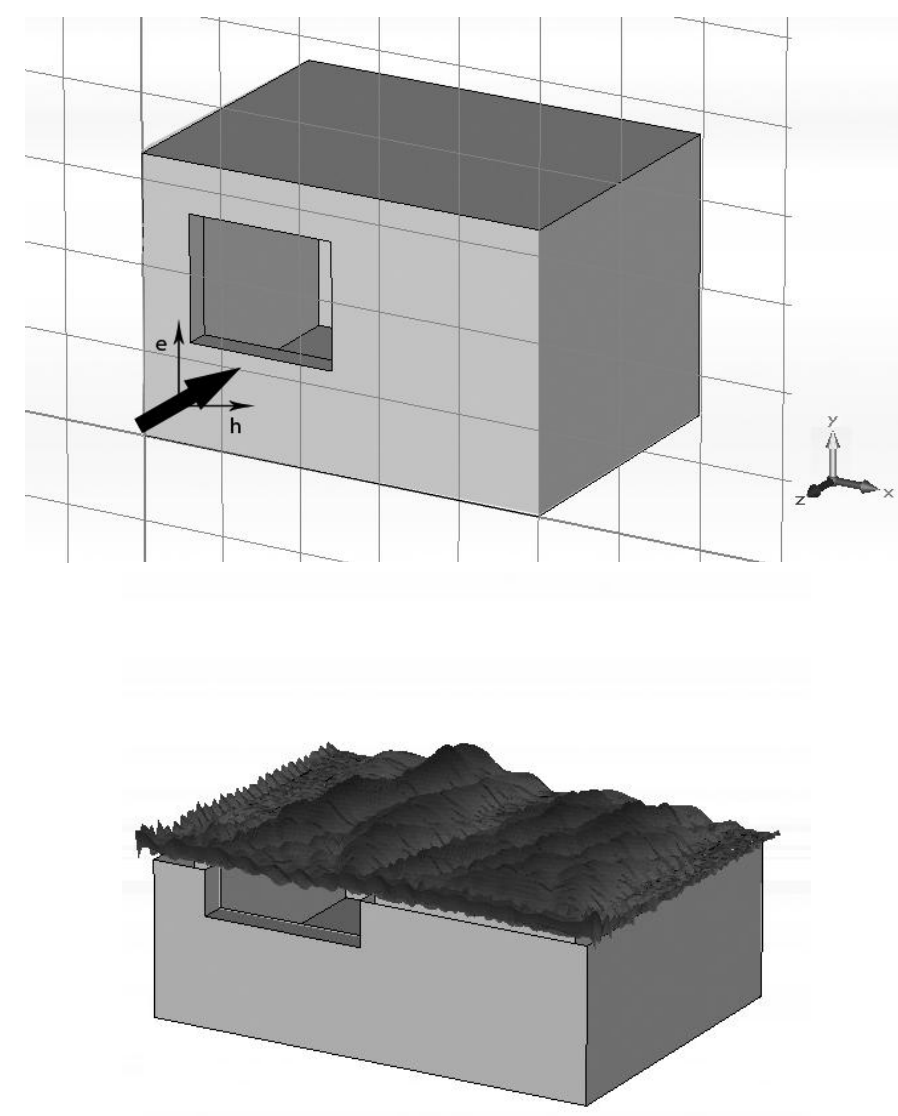

1. ábra. A modellépület rajza. Mérete: $5 m$ x 3,6m x 3,3m falvastagság 0,3m és az elektromos mezö grafikus ábrázolása $3 D$-ben

A szimulációkban azt vizsgáltam, hogy különböző építőanyagok alkalmazása esetén hogyan változik, ha változik a belső elektromágneses tér. A vizsgált frekvenciatartomány $1 \mathrm{GHz}$, ami nagyon közel van a 900MHz-es mobiltelefon hálózat frekvenciájához. A térerősség $1 \mathrm{~V} / \mathrm{m}$, mérési magasság padlóvonaltól 1,4m.

Az első teszt sorozatban teljesen zárt (nyílás nélküli) belső teret vizsgáltam, hogy a nyílások ne befolyásolják az eredményt Tégla és beton építőanyagok alkalmazásánál semmit sem csökken, vasalt beton szerkezetnél már tapasztalható némi árnyékolás. A mérési adatokat az 1. táblázat tartalmazza.

1. táblázat. Beltéri elektromos és mágneses tér különbözö épitöanyagok esetén

\begin{tabular}{|c|c|c|}
\hline Építőanyag & max. elektromos térerősség & max. mágneses térerősség \\
\hline Tégla & $1,23(0,8) \mathrm{V} / \mathrm{m}$ & $0,00398 \mathrm{~A} / \mathrm{m}$ \\
\hline Beton & $1,2(0,9) \mathrm{V} / \mathrm{m}$ & $0,00525 \mathrm{~A} / \mathrm{m}$ \\
\hline Vasalt beton 20x20 rács & $1,05(0,95) \mathrm{V} / \mathrm{m}$ & $0,006318 \mathrm{~A} / \mathrm{m}$ \\
\hline Vasalt beton 10x10 rács & $0,9(0,7) \mathrm{V} / \mathrm{m}$ & $0,004767 \mathrm{~A} / \mathrm{m}$ \\
\hline
\end{tabular}

A táblázatból az is látható, hogy tégla és beton falnál a belső térerősség nagyobb, mint a besugárzott térerősség. Ez a belső térben történt reflexiókkal magyarázható. Zárójelben a fal utáni 0,5 méteren számolt térerősséget, a zárójel előtt a belső térben mért maximumot adom meg. 
Nyílások elhelyezésével (amik mindennapi életünkhöz elengedhetetlenek) a belső elektromágneses tér megnövekszik, hiszen a hullámok akadálytalanul jutnak a belső térbe. A szimulációkból kiderül, hogy a visszaverödések hatására ez zárt térben akár 1,5-2 szeres növekedés is lehet. Nyílások elhelyezése után a falak anyagának változtatása szinte nem befolyásolja a belső elektromágneses tér maximumokat.

\section{Következtetések / Összefoglaló}

Szükséges, de nem elegendő egy építőanyag bizonyos fal szakaszon mért vagy számolt dielektromos tulajdonságait ismerni és árnyékoló hatékonyságát $(\mathrm{dB})$ megadni, mert egy helyiségben, belső térben a visszaverődésekből felhalmozódások jönnek létre. A távközlésben használt frekvenciák megválasztásának célja, hogy áthatoljanak a falakon, amit elektromosan vezető anyaggal lehet árnyékolni. A vasalt szerkezetek már mutatnak némi csökkentést, de mindez a vasalatok közötti távolság és kapcsolat függvénye. Az üvegezett felületek az épületek ilyen szempontból leggyengébb pontjai, mivel szinte semmit sem védenek, mint ahogy a hőszigetelő képességüket, az elektromos árnyékoló képességüket is növelni kell. Ez felveti az árnyékoló anyagok helyének és anyagának jól megválasztásának kérdését, amit a cikk megírása alatt is vizsgálok.

\section{Irodalom}

[1] PA Vroon: Ziekmakende Gebouwen en de evolutie van de mens. Bouwfysica 2, 1991 18-25 oldal

[2] Afsar, M.N., Birch, J.R., Clarke, R.N: The measurement of the properties of materials, IEEE, Proceedings of the IEE, Vol.47.No 1, 1986.

[3] Landrnn, O., Feuerstein, M.J., Rappaport, T.S: A comparison of Theoretical and empirical reflection coefficients for typical Exterior wall surfaces in a mobile radio environment, IEE Transactions on Antennas and Propagation, vol.44, No.3. 1996

[4] Shah, M.A., Hasted, J.B., Moore, L: Microwave absorption by water in building materials: Aerated concrete., British J. of Applied Physics, Vol. 16, 1965, 1747-1754.oldal

[5] Hasted, J.B., Shah, M.A: Microwave absorption by water in building materials, British J. of Avvlied Physics, vol.15, 1964, 825-836.oldal

[6] Richalot, E., Bonilla, M. et al:, Electromagnetic propagation into reinforced-concrete walls, IEEE Trans. Microwave Theory and Techniques, vol.48, No.3, 2000, 357-366.oldalak

[7] Stevels, J.M: The electrical properties of glass, Handbuch der Physik, Vol. 20, Berlin. 1957

Vizi Gergely Norbert, doktorandus

Munkahely: SZIE-YMÉTK Építészmérnöki Intézet

Cím: 1146, Magyarország, Budapest, Thököly út 74

Telefon / Fax: +36-1 -2521270

E-mail: Vizi.Gergely.Norbert@ybl.szie.hu 